\title{
THE ADOPTION AND USE OF NEW INFORMATION AND COMMUNICATION TECHNOLOGIES AT THE LEVEL OF CEE-EU COUNTRIES \\ Mihai Costea $^{1}$, Gabriela Arionesei ${ }^{2}$, Cristian-Valentin Hapenciuc ${ }^{3}$
}

\begin{abstract}
This paper focuses on determining the current state of adoption of new information and communication technologies by the population of EU countries from the Central and Eastern parts of Europe (referred in the paper as CEEEU countries). We have conducted a detailed analysis between Romania and Bulgaria because there are historical, geographical, political and economic similarities between these two neighbouring countries. In order to objectively reflect the results of the comparative analysis at the regional level, we have used the data provided by the World Economic Forum through the Competitiveness Index, the International Institute for Management Development through the Competitiveness Yearbook and the International Telecommunication Union through the ICT Development Index. The results of the comparative analysis reflect many regional disparities. At the same time, it can be noticed that both Romania and Bulgaria are the countries with the weakest results regarding the penetration rate of Internet accessibility in their populations, a fact which leads to a low degree of adaptability of the human capital to new information technologies and, implicitly, a low rate of adoption of the Internet in the sphere of business and public services. This is explained by the insufficient development of ICT infrastructure in the rural area, caused by numerous factors such as insufficient economic development and the low purchasing power of the population, but also by the relatively low level of education in ICT use. Although the influx of information and communication technologies occurred after the 1990s, namely at a time when even countries like Romania or Bulgaria were already part of the free market economy, the gaps recorded during the communist regime (economic, but especially socio-cultural), were apparently difficult to recover in the years to come, therefore this upsurge in information technology has been somewhat delayed in the South-Eastern area of Europe.
\end{abstract}

JEL Classification Numbers: L86, J24; DOI: http://dx.doi.org/10.12955/cbup.v6.1135

Keywords: new information and communication technologies, CEE-EU countries, Romania, Bulgaria, competitiveness.

\section{Introduction}

New information and communications technologies (new ICTs) have revolutionized business models and public services around the world. Thus, communication has become faster, easier and more efficient due to the technological advances in recent years. Smart mobile phones (smartphones), wireless technology, Wi-Fi Internet, Social Media with all its elements (social networks, blogs, microblogs, podcasts, video-sharing platforms, etc.), and virtual reality are just a few examples of new technologies that allow communication and which have exerted a major influence in all areas of economic activity.

Despite the specific challenges of adopting and using new technologies in developing countries, businesses in all areas of activity are given numerous opportunities, especially in terms of access to international markets and the acquisition of a competitive position in relation to competition.

However, in order for these opportunities to be exploited, there is a need for human resources very well anchored to new trends and prepared for the adoption and use of new technologies on a large scale. In this context, we have chosen to determine the degree of use of these technologies at the level of the population in Romania as well as in the other EU countries in Central and Eastern Europe (Czech Republic, Croatia, Poland, Slovenia, Slovakia, Hungary, Estonia, Lithuania, Latvia and Bulgaria), based on the data provided by the World Economic Forum, the International Institute for Management Development and the International Telecommunication Union.

It is worth mentioning that the underlying rationale behind the choice of these countries also focused on their socialist past, which was a further motivation to see how they have evolved and to what extent these countries have succeeded in adopting new information and communication technologies over the last few years. We have proposed to make a somewhat more detailed analysis between Romania and its neighbouring country Bulgaria, because in a simple comparison between the two countries we can observe many similarities, historically, politically, economically and socio-culturally.

\section{Literature Review}

One of the identified factors through which the world will constantly experience change is technology. In the actual society where there is the trend of trying to make information available in the right form to the right user, both at the personal and organizational levels, and at the right time, the tempt to cope

\footnotetext{
${ }^{1}$ Ștefan cel Mare University of Suceava, Romania, mihai_costeaa@yahoo.com

2 Ștefan cel Mare University of Suceava, Romania, gabriela.arionesei@gmail.com

${ }^{3}$ Ștefan cel Mare University of Suceava, Romania, valentinh@seap.usv.ro
} 
with great amount of information has led to the need for a more sophisticated way of handling information faster and better.

According to Rouse from TechTarget, information and communication technologies have become a fundamental element in the development of a global knowledge-based economy and their importance will undoubtedly increase given the fact that the need for knowledge and innovation in everyday socio-economic activities is steadily increasing,With the help of new information and communication technologies, virtual proximity can be a substitute for physical proximity in the case of standard transactions, but as Morgan (2014) said "it is not the case for highly complex and ambiguous business deals".

The impact that new information and communication technologies have in the economic growth of the $21^{\text {st }}$ century is obvious. An adequate impact, a real openness towards new ICTs may ensure the premises of economic growth, determining at the same time the increase in credibility and the reduction of frictions among countries. In a paper by Georgescu \& Popescu (2015), they state that an important stage may be represented by the promotion of tangible, intangible, mobile, non-mobile and especially the cultural and spiritual heritage values which by means of the new information and communication technologies can speed up the transfer of knowledge development and extend transnational scientific collaboration.

In the beginning, new information and communication technologies were considered important factors for economic growth, but nowadays they are synonymous with sustainable development. Their impact on society enables significant improvements in many sectors of activity and their added value resides mainly in the manipulation and diffusion (in many cases free on the Internet) of information. As we can see in the work of Chaminade \& Plechero (2012) the access to global innovation networks is unfortunately unequal in the various regions of the world. While some regions are considered real knowledge hubs which can connect anytime to the global knowledge flows, there are areas where these remain sporadic. Careful attention should be paid to the sharing of knowledge within virtual communities due to the unprecedented evolution of the Internet and its impact on the information systems.

However, Fransman (2010) found that in order to play its constructive role the new ICT sector will need to both innovate and invest. Innovation and its related investment must therefore be the central objective of the players who make up this sector and benefit from its output, this include corporate players, private consumers/users, government policy-makers and regulators.

\section{Results and discussion}

\section{New Information Technologies in the World Economic Forum Methodology}

In order to substantiate international comparisons, the World Economic Forum started publishing its Global Competitiveness Report annually since 2005, and the version of 2016-2017 is an analysis of the competitiveness of 138 countries through an index based on 12 pillars. One of these pillars is called Technology Readiness and measures the agility with which an economy adopts to existing technologies to enhance the productivity of its industries, with a particular focus on its ability to rely on Information and Communication Technologies in order to increase efficiency and innovation.

According to this report, Lithuania holds the leading position in the regional rankings (26th overall in the world), with 5.8 points, followed by the Czech Republic, on the 28th position at the global level, with 5.8 points. On the other hand, countries with the lowest ICT use rate are Hungary (50th place), Poland (48th place) and Romania (43rd place) (Table 1).

After analysing the data in Table 2 we find that, compared to the other states in the region, Romania is on the last position with regard to the Internet penetration rate in the country's population. However, we can see that the situation in the two neighbouring countries - Romania and Bulgaria - is relatively balanced, with a sensible superiority (of about 1\%) of Bulgaria. Moreover, Romania is on the last position regarding the subscription to fixed broadband networks, on the third position in terms of Internet bandwidth (measured in kb / s / user), after Lithuania and Slovenia and eighth out of the eleven countries examined in terms of subscriptions to mobile Internet.

With the emergence and development of smartphones over the last decade, the use of Internet services has become much easier. Many of the operations that were once performed on a desktop PCs or 
laptops have become much more accessible and faster realized on mobile phones. This has made the number of Internet subscriptions for mobile devices steadily increase, thus gaining ground against the number of fixed Internet subscriptions. For example, on average in Romania 63 out of 100 inhabitants have Internet access on their mobile phones while only 20 out of 100 have a fixed Internet subscription. In Bulgaria, the Internet access rate on mobile terminals is higher with an average of 81 out of 100 people have Internet access on the phone while 22 out of 100 have subscribed to a fixed Internet subscription.

\begin{tabular}{|l|l|c|c|}
\hline Table 1: Romania's position in the general ranking of ICT use \\
\hline \multirow{1}{*}{} & Country & \multicolumn{2}{|c|}{ The use of ICT } \\
\cline { 2 - 4 } & $\begin{array}{c}\text { Ranked in the } \\
\mathbf{1 3 8} \text { countries }\end{array}$ & Score \\
\cline { 2 - 4 } & Bulgaria & 36 & 5,5 \\
\cline { 2 - 4 } & Croatia & 28 & 5,2 \\
\cline { 2 - 4 } & Czech Republic & 50 & 5,8 \\
\cline { 2 - 4 } & Hungary & 48 & 4,6 \\
\cline { 2 - 4 } & Poland & $\mathbf{4 3}$ & 4,8 \\
\cline { 2 - 4 } & Romania & 56 & $\mathbf{4 , 9}$ \\
\cline { 2 - 4 } & Slovakia & 33 & 4,4 \\
\cline { 2 - 4 } & Slovenia & 38 & 5,6 \\
\cline { 2 - 4 } & Estonia & 26 & 5,4 \\
\cline { 2 - 4 } & Lithuania & 32 & 5,8 \\
\cline { 2 - 3 } & Latvia & 5,6 \\
\hline Source: The Global Competitiveness Report, 2016-2017 \\
\hline
\end{tabular}

Table 2: Comparative analysis of Romania to CEE-EU countries in terms of ICT use

\begin{tabular}{|l|l|l|l|l|l|l|l|l|l|l|l|l|}
\hline \multirow{2}{*}{} & \multicolumn{2}{|c|}{ Romania } & \multicolumn{2}{c|}{ Bulgaria } & \multicolumn{2}{c|}{ Hungary } & \multicolumn{2}{c|}{ Poland } & \multicolumn{2}{c|}{ Croatia } & \multicolumn{2}{c|}{$\begin{array}{c}\text { Czech } \\
\text { Republic }\end{array}$} \\
\cline { 2 - 14 } & Position & Score & Position & Score & Positio & Score & Position & Score & Position & Score & $\begin{array}{c}\text { Positio } \\
\text { n }\end{array}$ & Score \\
\hline V1 & 70 & 55,8 & 58 & 56,7 & 42 & 72,8 & 53 & 68 & 48 & 69,8 & 28 & 81,3 \\
\hline V2 & 44 & 19,8 & 41 & 22,4 & 31 & 27,4 & 46 & 19,5 & 39 & 23,2 & 25 & 27,9 \\
\hline V3 & 22 & 146 & 23 & 145,2 & 62 & 55,4 & 43 & 86,6 & 49 & 72,4 & 28 & 119,8 \\
\hline V4 & 50 & 63,5 & 27 & 81,3 & 86 & 39,8 & 55 & 60,2 & 33 & 75,4 & 42 & 68,8 \\
\hline
\end{tabular}

\begin{tabular}{|l|l|l|l|l|l|l|l|l|l|l|l|l|}
\hline & \multicolumn{2}{|c|}{ Romania } & \multicolumn{2}{c|}{ Slovakia } & \multicolumn{2}{c|}{ Slovenia } & \multicolumn{2}{c|}{ Estonia } & \multicolumn{2}{c|}{ Lithuania } & \multicolumn{2}{c|}{ Latvia } \\
\cline { 2 - 15 } & Position & Score & Position & Score & $\begin{array}{c}\text { Positi } \\
\text { on }\end{array}$ & Score & Position & Score & Position & Score & $\begin{array}{c}\text { Positio } \\
\text { n }\end{array}$ & Score \\
\hline V1 & 70 & 55,8 & 21 & 85 & 40 & 73,1 & 15 & 88,4 & 44 & 71,4 & 30 & 79,2 \\
\hline V2 & 44 & 19,8 & 38 & 23,3 & 29 & 27,6 & 22 & 28,7 & 27 & 27,8 & 35 & 25,1 \\
\hline V3 & 22 & 146 & 95 & 17,2 & 20 & 154,6 & 78 & 30,9 & 18 & 158 & 30 & 111,9 \\
\hline V4 & 50 & 63,5 & 44 & 67,5 & 69 & 52 & 8 & 114,3 & 37 & 74,2 & 47 & 67 \\
\hline
\end{tabular}

Source: The Global Competitiveness Report, 2016-2017

Legend: V1 - Internet penetration rate in the country's population (\% of population), V2 - Fixedbroadband Internet subscriptions (per 100 inhabitants), V3 - Internet bandwidth (kb / s / user), V4 Mobile broadband subscriptions (per 100 inhabitants)

New Information Technologies in the Methodology of the International Institute for Management Development

The International Institute for Management Development (IMD) has proposed a model of competitiveness assessment similar to that proposed by the World Economic Forum, but with a number of differences. The IMD provides an overview of 61 economies and is based on the analysis of over 340 competitiveness criteria / variables.

As of the year 2016, Romania ranks 9th out of the 61 analysed countries in terms of mobile telephony costs, a fact which means that in Romania the costs are among the lowest compared to the level of the analysed countries. Romania also ranks $14^{\text {th }}$ out of 161 countries in terms of exports of ICT services, 
21st in terms of cyber security and 22nd in terms of Internet browsing speed. At the same time, if we relate to the people's skills to work with new information and communication technologies, Romania is ranked among the last, which however shows that despite the fact that we are a country exporting ICT products and services, the degree of familiarity of the population with these technologies is still low.

The IMD data on cyber security show that as of the year 2014, Romania was on the 27th position of the 61 analysed countries, wand was below other countries in the CEE region like Estonia, Poland, Latvia and Slovakia. Another analysed indicator is communication technology, namely the extent to which it meets the requirements to satisfy the business environment of the analysed countries. From this point of view, Romania ranks 32nd out of 61 countries, i.e. at the middle of the ranking, including at the regional level. The same situation is also encountered in terms of coverage of the connectivity of individuals and businesses through telecom and IT services, Romania being ranked 30th out of 61 countries (Table 3).

\begin{tabular}{|l|l|c|c|c|c|}
\hline \multicolumn{6}{|l|}{ Table 3: Ranking CEE-EU countries in terms of ICT variables } \\
\hline & Cyber security & $\begin{array}{c}\text { Ability to work } \\
\text { with ICT }\end{array}$ & $\begin{array}{c}\text { Communication } \\
\text { technology (voice } \\
\text { and data) }\end{array}$ & $\begin{array}{c}\text { Connectivity } \\
\text { (Telecom, IT) }\end{array}$ \\
\hline Romania & 27 & 48 & 32 & 30 \\
\hline Bulgaria & 54 & 39 & 29 & 35 \\
\hline Hungary & 47 & 45 & 33 & 41 \\
\hline Poland & 20 & 29 & 39 & 40 \\
\hline Slovakia & 25 & 42 & 8 & 20 \\
\hline Slovenia & 29 & 33 & 41 & 36 \\
\hline Czech Republic & 34 & 26 & 24 & 18 \\
\hline Croatia & 43 & 47 & 38 & 39 \\
\hline Lithuania & 32 & 24 & 4 & 15 \\
\hline Latvia & 21 & 10 & 1 & 23 \\
\hline Estonia & 7 & 60 & 20 & \\
\hline Source: IMD Competitiveness Year Book, 2014 & & \\
\hline
\end{tabular}

New Information Technologies in the Methodology of the International Telecommunication Union

The International Telecommunication Union annually calculates an ICT Development Index (IDI) based on a range of internationally agreed information and communication technology indicators. IDI thus becomes a valuable tool for the comparative evaluation of the most important indicators of measuring the information society. From a methodological point of view, the index is based on 11 ICT indicators, grouped into three groups as follows:

- ICT access (Fixed-telephone subscriptions per 100 inhabitants, Mobile cellular telephone subscriptions per 100 inhabitants, International Internet bandwidth per internet user, Percentage of households with a computer, Percentage of households with Internet access);

- ICT use (Percentage of individuals using the Internet, Fixed broadband subscriptions per 100 inhabitants, Active mobile-broadband subscriptions per 100 inhabitants);

- ICT skills (Mean years of schooling, Secondary gross enrolment ratio, Tertiary gross enrolment ratio).

The International Telecommunication Union calculates this index on a yearly basis on a scale from 1 to 10 ( 1 - minimum score related to the minimum degree of development of information and communication technologies, 10 - maximum score), based on reporting from no less than 175 countries. According to the IDI methodology, Romania is the least developed country in terms of ICT, with the lowest position at the regional level and the 60th position in the world with 6.26 points (Table 4).

Table 5 shows a comparative analysis presenting Romania versus Bulgaria in terms of IDI index determination, the source data being validated by the World Bank.As we can see, Romania is outpacing their neighbouring country of Bulgaria only in terms of Internet bandwidth, the percentage of households holding a computer and the percentage of households with an Internet connection. However, Bulgaria's population is somewhat more open to the use of new information technologies, 
especially since the differences between the two countries in the number of mobile subscriptions per 100 inhabitants are much higher for Bulgaria, as well as the number of wireless / mobile Internet subscriptions per 100 inhabitants.

Table 4: ICT (IDI) Development Index in CEE-EU countries for 2015 and 2016

\begin{tabular}{|l|l|l|l|l|}
\hline $\begin{array}{c}\text { Position/175 } \\
\mathbf{2 0 1 6}\end{array}$ & Country & IDI 2016 & $\begin{array}{c}\text { Position/175 } \\
\mathbf{2 0 1 5}\end{array}$ & IDI 2015 \\
\hline 18 & Estonia & 8,07 & 18 & 7,95 \\
\hline 32 & Czech Republic & 7,25 & 31 & 7,20 \\
\hline 33 & Slovenia & 7,23 & 32 & 7,10 \\
\hline 39 & Lithuania & 7,10 & 34 & 7,00 \\
\hline 40 & Latvia & 7,08 & 37 & 6,88 \\
\hline 41 & Croatia & 7,04 & 41 & 6,83 \\
\hline 42 & Slovakia & 6,96 & 44 & 6,69 \\
\hline 48 & Hungary & 6,72 & 46 & 6,60 \\
\hline 49 & Bulgaria & 6,69 & 50 & 6,43 \\
\hline 50 & Poland & 6,65 & 47 & 6,56 \\
\hline 60 & Romania & 6,26 & 60 & 5,92 \\
\hline
\end{tabular}

Source: Measuring the Information Society Report 2016, published by International

Telecommunications Union

Table 5: Comparison of Romania versus Bulgaria in terms of IDI indicators
\begin{tabular}{|l|c|c|}
\hline & ROMANIA & BULGARIA \\
\hline Position in overall IDI ranking 2016 & $\mathbf{6 0}$ & $\mathbf{4 9}$ \\
\hline IDI value 2016 & $\mathbf{6 , 2 6}$ & $\mathbf{6 , 6 9}$ \\
\hline The number of fixed telephony subscriptions per 100 inhabitants & 19,79 & 23,26 \\
\hline The number of mobile subscriptions per 100 inhabitants & 107,14 & 129,27 \\
\hline Internet bandwidth per user (bit / s) & 146 & 145 \\
\hline Percentage of households holding a computer & 68,69 & 59,04 \\
\hline Percentage of households with an Internet connection & 67,71 & 59,14 \\
\hline Internet penetration rate in the country's population (\%) & 55,76 & 56,66 \\
\hline Number of wire / fixed Internet subscriptions per 100 inhabitants & 19,77 & 22,41 \\
\hline $\begin{array}{l}\text { The number of wireless Internet / mobile Internet subscriptions per } \\
\text { 100 inhabitants }\end{array}$ & 63,53 & 81,29 \\
\hline The average number of school years & 10,64 & 10,57 \\
\hline Secondary education enrollment rate & 97,89 & 100,88 \\
\hline Tertiary education enrollment rate in the population & 52,17 & 70,79 \\
\hline
\end{tabular}

Source: author's processing based on data provided by the ITU - International Telecommunications Union, 2016

We also note that Romania is the country with the lowest Internet penetration rate, at the level of the CEE-EU region. In Romania, 55.76\% of the population has some form of Internet access while in Bulgaria the percentage is $56.66 \%$. In any case, both countries are amongst the last positions at regional level, given that in the other nine countries analysed, the Internet penetration rate is around $70-80 \%$, even close to $90 \%$, as in the case of Estonia (Figure 1). The data presented are validated both by the World Economic Forum through the Global Competitiveness Index and the World Bank reports.

Measuring the Information Society Report (2015) highlighted the fact that Romania is one of the European leaders (with Sweden, Latvia and Finland) in terms of ultrafast access to broadband Internet (speeds of $100 \mathrm{Mbit} / \mathrm{s}$ and higher). A key factor underpinning high-speed and affordable Internet access was represented by the so-called neighbourhood networks, run and managed by small Internet service providers that have spread in Romania after 2000. However, these neighbourhood networks were concentrated mainly in urban areas while most rural areas had no access to Internet services at all. A very low population density, as well as a very low level of income in rural areas have made it more difficult to attract investors to deploy Internet networks. This explains broadly why the 
penetration rate of the Internet in the country's population is still at the lowest level in the CEE-EU region.

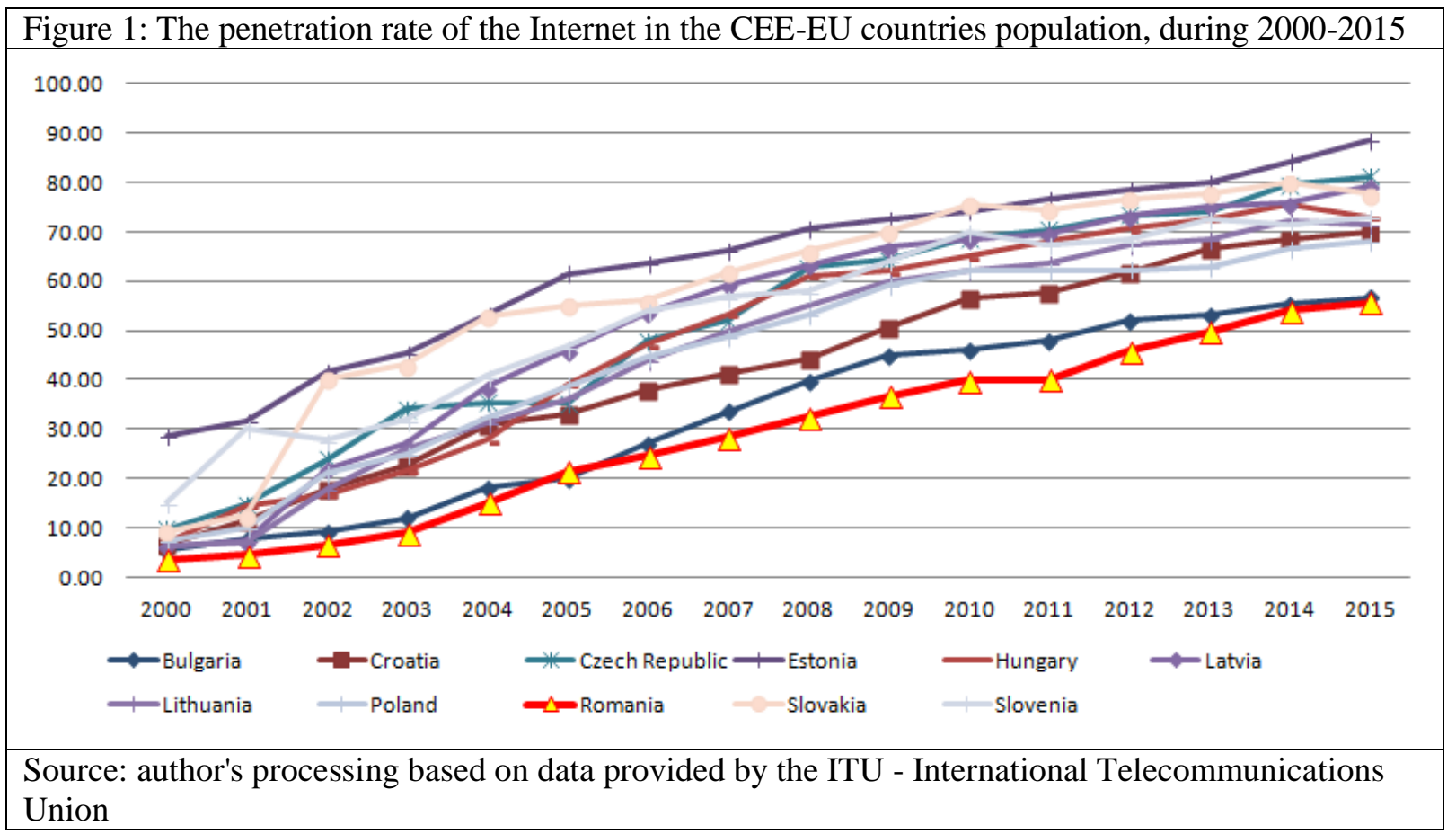

\section{Conclusions}

Following the analysis of the data provided by the World Economic Forum, the International Institute for Management Development, and the International Telecommunication Union, we found an important gap between Romania and the other CEE-EU countries in terms of the availability and use of the ICT infrastructure. From this point of view Romania is ranked, most of the time, on the last positions in the regional ranking. Although Romania has a fairly well-established network (especially in urban areas) and Internet browsing speed is one of the best at the European level, the Internet penetration and use rate in the country's population is quite low compared to the other states in the region. This is explained by the insufficient development of ICT infrastructure in the rural area, caused by numerous factors such as insufficient economic development and the low purchasing power of the population, but also by the relatively low level of education in ICT use. Although the influx of information and communication technologies occurred after the 1990s, namely at a time when even countries like Romania or Bulgaria were already part of the free market economy, the gaps recorded during the communist regime (economic, but especially socio-cultural), were apparently difficult to recover in the years to come, therefore this upsurge in information technology has been somewhat delayed in the South-Eastern area of Europe.

Only in recent years has Romania started to make some more significant progress regarding the access of the population to the Internet and reducing disparities compared to other European countries. However, despite these developments the digitization rate of the economy including public services as well as the level of digital skills are still low in Romania compared to other EU countries.

\section{References}

Chaminade, C., \& Plechero, M. (2012). Do regions make a difference? Exploring the role of different regional innovation systems in global innovation networks in the ICT industry (No. 2012/2). Lund University, CIRCLE-Center for Innovation, Research and Competences in the Learning Economy.

Fransman, M. (2010). The new ICT ecosystem: Implications for policy and regulation. Cambridge University Press, 978-0521-19131-9.

Georgescu, M., \& Popescul, D. (2015). The impact of new information and communication technologies on the creation and dissemination of knowledge inheritance. Procedia-Social and Behavioral Sciences, 188, 122-129.

ICT Development Index (2017). Retrieved from http://www.itu.int/net4/ITU-D/idi/2016/index.html.

IMD World Competitiveness Center. Retrieved from http://www.imd.org/wcc/wcy-world-competitiveness-yearbook/. 
IMD Competitiveness Year Book (2014). Retrieved from http://dspace2.conicyt.cl/bitstream/handle/10533/91106/IMD_WCY-2014.pdf?sequence=1.

Measuring the Information Society Report (2016). Retrieved from http://www.itu.int/en/ITUD/Statistics/Documents/publications/misr2016/MISR2016-w4.pdf.

Morgan, K. (2004). The exaggerated death of geography: learning, proximity and territorial innovation systems. Journal of economic geography, 4(1), 3-21.

TechTarget, Definition of ICT (information and communications technology, or technologies). Retrieved from http://searchcio.techtarget.com/definition/ICT-information-and-communications-technology-or-technologies.

World Bank Database. Retrieved from http://data.worldbank.org/indicator/IT.CEL.SETS.P2?locations=RO. 